\title{
Impact of replacement of soybean meal with guar korma meal on growth performance and some physiological parameters of the Nile Tilapia (Oreochromis niloticus) fingerlings.
}

\author{
Hussein, M. S ${ }^{1}$, Abdel-Aal, M. M. ${ }^{2}$, El-Zayat, A. M. ${ }^{1}$ and El-Kady, A. E. A. ${ }^{1}$ \\ 1- Al-Azhar University, Faculty of Agriculture, Department of Fish Production, Cairo, \\ Egypt. \\ 2- Central Laboratory for Aquaculture Research, Abbassa, Abou-Hammad, Sharkia, Egypt.
}

\section{ABSTRACT}

This study aimed to evaluate the partial and complete substitution of soybean meal as crude protein by various levels $(0 \%, 25 \%, 5 . \%, 75 \%$ and $100 \%)$ of guar korma meal (GKM) (Cyamopsis tetragonolobus) in the Tilapia diet on growth performance, feed utilization, carcass composition and physiological parameters (ALT, AST and glucose level). Water quality parameters were checked and evaluated on a daily basis and the other factors were analyzed fortnightly of the Nile Tilapia (Oreochromis niloticus) fingerlings. Five isonitrogenous (30\% crude protein) and isocaloric (4300 kcal/ $\mathrm{kg}$ gross energy) diets were formulated to contain guar korma meal at $0,9.5,18.5,27.75$ and $37 \%$ crude protein levels by replacing soybean meal at $0,25,50,75$ and $100 \%$ crude protein, respectively. An experimental diet containing $37 \%$ soybean meal and $0 \%$ guar meal protein was used as a control diet. All fish were fed at $5 \%$ body weight / day in three replicates. Results of the present study concluded that guar korma meal is a promising ingredient source of protein in aqua feeds and can be included up to $18.5 \%$ crude protein by replacing $50 \%$ of soybean meal crude protein during feed formulation for the Nile Tilapia (O. niloticus) diets system without affecting the growth performance and feed utilization.

Keywords: Oreochromis niloticus; soybean, meal replacement, guar korma,growth performance, feed utilization; water quality, physiological parameters.

\section{INTRODUCTION}

Tilapias are known to be an important component of subsistence fisheries for thousands of years and are being described as the second most important farmed fish globally next to carps and also as the most important aquaculture species of the twenty-first century. The Nile tilapia (Oreochromis niloticus) is one of the fastest growing, most valuable and economical freshwater fish and is the main cultured species in many parts of the world, it is responsible for the significant increase in global tilapia aquaculture production due to its suitability for farming in a wide array of culture systems, in ponds and cages, ranging from extensive, low-input culture to intensive systems. It is accounted for about $83 \%$ of total tilapias produced worldwide. It is native to Egypt and distributed to all parts of the world for its excellent biological characteristics (Singh and Lakra, 2012).

Feed is an important critical input which alone contributes more than $60 \%$ of operating cost of aquaculture system. Thus, the increase in aquaculture production must be supported by a corresponding increase in the production of formulated feeds for corresponding increase (FAO, 2012).

Cost effective feed stuffs that are compatible with fish species, easily digested and readily available are the demand of the industry and can play pivotal role in the advancement of fish industry (Iqbal et al., 2015). Guar plant (Cyamopsis 
tetragonoloba) is a drought-tolerant legume that can be grown in unsuitable conditions. The minimum crude protein percentage of guar meal is rated at $50 \%$ compared to 48\% of soy bean meal (Mathur and Mathur, 1989 and Conner, 2002).

In fish, as in mammals, guar gum tends to increase digesta viscosity and decrease gastric emptying time, leading to a delay of nutrient absorption (Storebakken 1985; Amirkolaie et al., 2005 and Leenhouwers et al., 2006). The increase in digesta viscosity may also be responsible for impairment of macronutrient digestibility, thus leading to growth and feed efficiency depression. Inclusion of small amounts of guar gum $(0.3 \%)$ in rainbow trout Oncorhynchus mykiss diets enhanced feces stability in water, indicating that soluble NSPs may improve processing of fecal wastes in this species (Brinker et al., 2005 and Brinker 2007, 2009). On the contrary, in the Nile tilapia Oreochromis niloticus, guar gum reduced feces stability due to its high water-binding capacity, thus not acting as appropriate feces binder in this species (Amirkolaie et al., 2005). Most available literature on soluble NSPs in fish focuses on growth, digestibility and feces characteristics, and there is little information available on its effect on glucose and lipid metabolism. Thus, while some studies reported that dietary supplementation with soluble NSP decrease blood glucose due to slower intestinal absorption of carbohydrates (Furuichi et al. 1983; Shiau et al. 1989), other studies were unable to show such effect (Kraugerud et al., 2007 and Leenhouwers et al., 2007). A reduction in both muscle and plasma cholesterol levels was reported in several fish species fed on soluble NSPs (Kraugerud et al., 2007 and Kumar et al., 2011).

Guar korma meal contains 13-18\% residual galactomannan gum (Anderson and Warnick, 1964 and Nagpal et al., 1971). The negative effects of adding guar korma meal on body weight and feed conversion ratio might be attributed to that guar korma meal contains $5-13 \%$ of dry matter triterpenoid guar saponin (Hassan et al., 2007). Guar meal contains other types of antinutritional factors: trypsin inhibitors, saponin, haemagglutinins, hydrocyanic acid and polyphenols have been identified (Gutierrez et al., 2007). The large saponin content of guar seed (up to 13\% DM) could have both antinutritionals effect and a positive antimicrobial activity (Hassan et al., 2010, Hussainet al., 2012 and Gupta et al. 2012).

The objective of the present study was to evaluate the potential of partial substitution $(0 \%, 25 \%, 5 \cdot \%, 75 \%$ and $100 \%)$ of guar korma meal (GKM) (Cyamopsis tetragonolobus) by for the expensive, soybean meal (SBM) in the fish diet on the growth performance, feed utilization, body composition, physiological parameters (ALT, AST and glucose level) of the Nile Tilapia (Oreochromis niloticus) fingerlings reared in cages in earthen ponds. Water quality will also be evaluated.

\section{MATERIALS AND METHODS}

\section{Study Area}

During the production season (2014), this work was carried out at a private fish farm in Kafr El-Sheikh Governorate, Egypt. The experimental fish, sex reversed mono sex Nile tilapia fingerlings (Oreochromis niloticus), were obtained from a commercial tilapia fish farm in Kafr El-Sheikh Governorate, Egypt, and were acclimated in $4-\mathrm{m}^{3}$ net cages before starting the feeding trial.

\section{Study period}

The study was carried out for a period of 112 days from $1^{\text {st }}$ July 2014 to $20^{\text {nd }}$ October 2014 in cages placed into earthen pond system. 


\section{Experimental design}

The feeding trial was conducted in five groups of healthy mono sex fingerlings Nile Tilapia (Oreochromis niloticus) fish in fifteen groups with $6 \mathrm{~m}^{3}(2 \times 3 \times 1 \mathrm{~m})$ net cages (in triplicate ); were placed in a $4200 \mathrm{~m}^{2}$ (one feddan ) earthen pond system, with a depth of $1.5 \mathrm{~m}$, with water flow. Net cages were set on wooden stales and attached to wooden structures. The pond was rectangular in shape, well exposed to sunlight, independent completely free from aquatic vegetation, basin conformation and bottom soil type were also similar. The pond has inlet and outlet facilities. The main source of water was drainage water. The embankment was well protected.

\section{Pond preparation}

Prior to the experiment, pond was de-watered and aquatic vegetations were cleaned. The dikes of pond were repaired. Pond was filled (on day-2) with water. Quicklime (on day-3) was applied to the pond by spreading methods at the rate of $100 \mathrm{~kg} /$ feddan. After one week of lime application the pond was fertilized with both of urea and TSP $5 \mathrm{~kg} /$ pond. TSP and urea were mixed together and dissolved in plastic bucket for 10-12 hours then applied to the pond. After 5 days of fertilizer application fingerlings of (all-male) Nile Tilapia (Oreochromis niloticus) were stocked in cages. The cages were suspended on the pond surface waters by direct attachment to wooden piers.

\section{Cages management}

The nets were cleaned regularly during feeding time. The dead fish were removed if observed any to keep the environment clean for fish. The cages were lifted from water every 3 days to check the net whether had any damage.

\section{Stocking of fingerlings}

The fish were kept for acclimatization at the experimental conditions for seven days before the trial began. After the groups were allocated and fish acclimatized, samples of fish were weighed using a digital scale and measured using a measuring board to obtain the initial samples of the groups. From this study, a total of 2250 fish (25 fish $/ \mathrm{m}^{3} \times 6 \mathrm{~m}^{3}$ /cage $\times$ triplicate group $\times 5$ alternative dietary source for tilapia) with a $10.0 \pm 0.01-10.04 \pm 0.03 \mathrm{~g}$ mean initial body weight were randomly stocked into fifteen $6 \mathrm{~m}^{3}$ net cages with 3 replicates per treatment. A completely randomized design was adopted, where five diets were fed to triplicate groups.

\section{Sampling of fish and Feeding}

Fish were sampled weekly (between 07:00 and 10:00 hours) during when the weights (Ohaus portable digital scale (model DIGI DS 671); $\pm 0.1 \mathrm{~g}$ ), standard and total length (measuring board; $\pm 1.0 \mathrm{~mm}$ ) and the number of fish were assessed for each treatment. At least fifty live fish in each cage -in-pond were randomly scooped out of each cage unit for their measurements and immediately returned to their respective cages. The cage nets were inspected and cleaned during each sampling.

Caged Nile Tilapia finger lings were fed twice a day at 10 AM and 3 PM with experimental pellet feed at the rate of $5 \%$ body weight. Feeding rate was adjusted weekly. Daily feed consumption (feed given to fish) and mortalities were recorded. Dead fish were replaced immediately with similar size specimens within the first ten days of culture. The amounts of feed in respective fish type were determined through the sampling that was carried out weekly throughout the culture period to monitor growth performance.

\section{Harvesting of fish}

At the end of the experiment, water was pumped out of pond and all fish from each experimental cages were harvested, recovered, weighed in kilograms and 
counted. The individual body weight and total fish weight were taken. The total length of fish was measured as well (Precision $=1 \mathrm{~mm}$ ).

\section{Analytical methods}

Samples of fish and nutritional composition were collected from several sacks and send for proximate analysis at the Central Laboratory for Aquaculture Research at Kafr El-Sheikh Governorate, Egypt. The proximate composition (moisture, crude protein, crude lipid and ash) of fish body composition have been carried out before and after the experiment according to the methods of AOAC (2005). The nutritional composition of the feed ingredients and composition of experimental diets ratio of test feeds were analyzed prior to diet formulation. (Tables $1 \& 2$ ).

Table 1: Proximate composition of the feed stuffs samples used in diet formulation ( $\%$ on dry matter basis) (Mean $\pm \mathrm{SD})(\mathrm{n}=3)$

\begin{tabular}{|c|c|c|c|c|c|}
\hline $\begin{array}{c}\text { Proximate composition } \\
(\%)\end{array}$ & Guar meal & $\begin{array}{c}\text { Soybean } \\
\text { meal }\end{array}$ & Fish meal & Corn meal & $\begin{array}{c}\text { Wheat } \\
\text { bran }\end{array}$ \\
\hline Dry matter (DM) & $92.47 \pm 0.21$ & $90.81 \pm 0.43$ & $91.33 \pm 0.08$ & $88 \pm 0.62$ & $89 \pm 0.35$ \\
\hline Crude protein (CP) & $51.85 \pm 0.43$ & $47.12 \pm 0.53$ & $72.31 \pm 0.07$ & $8.5 \pm 0.48$ & $16.4 \pm 0.52$ \\
\hline Ether extract (EE) & $4.93 \pm 0.38$ & $3.14 \pm 0.11$ & $8.07 \pm 0.03$ & $3.6 \pm 0.27$ & $4 \pm 0.46$ \\
\hline Crude fiber (CF) & $8.32 \pm 0.09$ & $7.22 \pm 0.17$ & $0.6 \pm 0.01$ & $2.3 \pm 0.15$ & $9.9 \pm 0.18$ \\
\hline $\begin{array}{c}\text { Total ash } \\
{ }^{1} \text { Nitrogen free extract } \\
\text { (NFE) }\end{array}$ & $4.79 \pm 0.34$ & $7.11 \pm 0.22$ & $16.62 \pm 0.06$ & $1.3 \pm 0.33$ & $5.3 \pm 0.42$ \\
\hline${ }^{2}$ Gross energy(GE) \\
Kcal/Kg
\end{tabular}

${ }^{1} \mathrm{NFE}$, nitrogen free extract Calculated by differences $=100-(\mathrm{CP}+\mathrm{CF}+\mathrm{EE}+\mathrm{Ash} \%)$.

${ }^{2} \mathrm{GE}$, gross energy value was estimated according to Jobling, (1983), using the 5.65, 9.45, and 4 for $\mathrm{CP}, \mathrm{EE}$ and NFE, respectively.

${ }^{3}$ DE Digestible energy was estimated according to Jobling, (1983), using digestible energy = gross energy X 0.75 .

\section{Fish grouping:}

The diets were substituted by guar korma meal (GKM) protein, and protein in soybean was replaced and diets were formulated to contain guar korma meal as follows:

1. Control diet $\left(D_{1}\right)$; without guar korma meal ( $0 \%$ GKM) with $100 \%$ soybean meal protein,

2. Diet $\left(\mathrm{D}_{2}\right)$; substituted by $(9.5 \%$ GKM protein) with $25 \%$ replacement of soybean protein,

3. Diet $\left(\mathrm{D}_{3}\right)$; substituted by $(18.5 \%$ GKM protein) with $50 \%$ replacement of soybean protein,

4. Diet $\left(D_{4}\right)$; substituted by $(27.75 \%$ GKM protein $)$ with $75 \%$ replacement of soybean protein,

5. Diet $\left(\mathrm{D}_{5}\right)$; substituted by $(37 \%$ GKM protein) with $100 \%$ replacement of soybean protein. 
Table 2: Percent ingredient composition of guar meal based diets and Proximate chemical analysis of the experimental diet (\% on dry matter basis).

\begin{tabular}{|c|c|c|c|c|c|}
\hline \multirow[b]{2}{*}{ Ingredient } & \multicolumn{5}{|c|}{ Experimental diets (Inclusion level \%) } \\
\hline & $\begin{array}{c}\text { D1 } \\
\text { (Control)KM 0\% }\end{array}$ & $\begin{array}{c}\text { D2 } \\
\text { GKM } 9.5 \%\end{array}$ & $\begin{array}{c}\text { D3 } \\
\text { GKM } \\
18.5 \% \\
\end{array}$ & $\begin{array}{c}\text { D4 } \\
\text { GKM } \\
27.75 \% \\
\end{array}$ & $\begin{array}{c}\text { D5 } \\
\text { GKM } \\
37 \% \\
\end{array}$ \\
\hline Fish meal (FM) & 10 & 10 & 10 & 10 & 10 \\
\hline Guar korma meal (GKM) & 0 & 9.5 & 18.5 & 27.75 & 37 \\
\hline Soybean meal (SBM) & 37 & 27.5 & 18.5 & 9.25 & 0 \\
\hline Corn meal & 25 & 26 & 29 & 31 & 33 \\
\hline Wheat bran & 18 & 17 & 14 & 12 & 10 \\
\hline Lin Oil & 4 & 4 & 4 & 4 & 4 \\
\hline Vit. Mix ${ }^{1}$ & 2 & 2 & 2 & 2 & 2 \\
\hline $\operatorname{Min}_{\mathrm{Mix}}{ }^{1}$ & 1 & 1 & 1 & 1 & 1 \\
\hline $\mathrm{CMC}^{2}$ & 3 & 3 & 3 & 3 & 3 \\
\hline Total & 100 & 100 & 100 & 100 & 100 \\
\hline \multicolumn{6}{|c|}{ Chemical analysis of the experimental diets ( \% on DM basis } \\
\hline Crude protein $(\mathrm{CP}) \%$ & 29.85 & 30.04 & 30.06 & 30.16 & 30.26 \\
\hline${ }^{3} \mathrm{GE}$ & 4282 & 4323 & 4387 & 4342 & 4360 \\
\hline${ }^{4} \mathrm{DE}$ & 3211 & 3242 & 3290 & 3257 & 3270 \\
\hline $\begin{array}{c}{ }^{5} \text { Protein/energy ratio }(\mathrm{P} / \mathrm{E}) \\
(\mathrm{mg} \mathrm{CP} / \mathrm{kcal} \mathrm{GE})\end{array}$ & 69.71 & 69.49 & 68.52 & 69.46 & 69.40 \\
\hline
\end{tabular}

${ }^{1}$ Vitamins \& minerals mixture/kg premix: Vitamin D, 0.8 million IU; A, 1.33g; D3, 1.68g; E, 6.66g; C, 16.8g; k, 0.8g; B1, 0.4g; Riboflavin 3.75g; B6 2.45g; B12, .33mg; NI, 9.42g; Pantothenic acid, 12.42g; Folic acid, 0.68g; Biotin, 16.6mg; BHT, 0.5g; Mn, 14.7g; Zn, 31.6g; Fe, 18.3g; 1, 0.62g; Selenium, 0.22g and Co, 6.8mg.

${ }^{2}$ Carboxy methyl cellulous.

${ }^{3} \mathrm{GE}$ (Gross energy) $(\mathrm{kcal} / 100 \mathrm{~g} \mathrm{DM})=\mathrm{CP} \times 5.65+\mathrm{EE} \times 9.45+\mathrm{NFE} \times 4$ calculated according to Jobling, (1983)

${ }^{4} \mathrm{DE}$ Digestible energy, estimated according to Jobling, (1983), using digestible energy $=$ gross energy X 0.75.

${ }^{5}$ Protein/energy $(\mathrm{P} / \mathrm{E})$ ratio $(\mathrm{mg} \mathrm{CP} / \mathrm{kcal} \mathrm{GE})=$ crude protein $\times 10000 /$ Gross energy.

\section{Essential amino acids composition of soybean meal and Guar Korma meal feed ingredients}

Amino acid was analyzed using HPLC after a 20 hour hydrolysation process with 6 molar $\mathrm{HCI}$ and a previous stabilisation with $\mathrm{Ba}(\mathrm{OH}) 2$ of tryptophan. Separation of amino acids was done using a einerhyperphil ODS $250 \times 4 \mathrm{~mm}$-column after pre-column derivatisation with OPA (orthophtalaldehyde) (ALVA, 1983 and Altmann, 1992). Amino acid compositions for the soybean meal and Guar Korma meal feed ingredients are shown in Table 3.

Table 3: Amino acids composition of soybean meal and Guar Korma meal feed ingredients and amino acids requirements for $O$. niloticus(\% of dry matter). (Data for EAAs requirement of Nile tilapia from Santiago \& Lovell 1988).

\begin{tabular}{|c|c|c|c|}
\hline Amino acid (\%) & Soybean meal & Guar korma meal & $\begin{array}{c}\text { EAAs requirement for } \\
\text { O. niloticus (g/kg DM) }\end{array}$ \\
\hline Argenine & 3.4 & 0.65 & 1.2 \\
\hline Histidine & 1.1 & 3.09 & 1 \\
\hline Isoleucine & 2.5 & 4.33 & 1.9 \\
\hline Leucine & 3.4 & 7.67 & 1.6 \\
\hline Lysine & 2.9 & 1.04 & 0.7 \\
\hline Methionine & 0.65 & 1.37 & 0.3 \\
\hline Cysetine & 0.76 & 0.47 & 1.1 \\
\hline Phenyl alanine & 2.2 & 4.09 & 0.5 \\
\hline Therionine & 1.7 & 3.03 & 1.1 \\
\hline Triptovan & 0.6 & 3.55 & 0.3 \\
\hline Valine & 2.4 & 5.48 & \\
\hline
\end{tabular}




\section{Biological evaluation:}

Fish from each cage were measured individually for weight and length every 7 days and at the end of the 112 days trial. Besides, growth parameters were measured according to NRC (2010) at the end of the culture period. Final harvesting was made through draining of water by water pump.

Growth performance for each treatment group was determined and feed utilization as follows:

Mean weight gain $=[$ final mean weight $(\mathrm{g})-$ initial mean weight $(\mathrm{g})]$

Where: W1 and W2 are the initial mean and final mean fish weight, respectively.

\section{Mean daily weight gain}

This was calculated as $(W f-W i) t-1$ where $W f$ is the final mean weight at harvest $(\mathrm{g}), \mathrm{Wi}$ is the initial mean weight at stocking and $\mathrm{t}$ is the time in days.

\section{Specific growth rate ( SGR)}

The specific growth rate for each treatment group was calculated using the formula:

$\mathrm{SGR}=\mathrm{SGR}=100 \times[(\operatorname{loge} W f-\log e \mathrm{Wi})] \mathrm{t}-1$

Where, loge is natural log, Wf is the final mean wet weight $(\mathrm{g}), W i$ is the initial mean wet weight and $t$ is the time in days (Ricker, 1975).

Food conversion ratio ( FCR) :

$\mathrm{FCR}=$ dry weight of feed consumed (Feed intake) $(\mathrm{g}) /$ wet weight gain $(\mathrm{g})$.

Condition Factor ( $K$ ) was calculated according to Tesch, (1971) as :

$K=100\left(\mathrm{Wt} / \mathrm{L}^{3}\right)$, where $K=$ condition factor, Wt is fish body weight $(\mathrm{g}), \mathrm{L}$ is total length $(\mathrm{cm})$.

Protein efficiency ratio $(\mathbf{P E R})=$ Wet body weight gain $(\mathrm{g}) /$ Crude protein fed (intake)

Where, Protein intake $=(\%$ protein in feed $x$ total diet consumed $) / 100$.

Protein productive value $(\mathbf{P P V})=($ Final fish body protein - initial body protein $) /$ Crude protein intake $\times 100$

i. Gross Yield $=$ No. of fish caught $x$ Average final weight

ii. Net Yield $=$ No. of fish caught $x$ Average weight gained

\section{Serum collecting and Haematological analysis}

At the end of the growth trial, after final weighing, blood samples were taken from ten fish samples from each treatment and control cages were randomly collected using hand net. The captured fish were degutted and cleaned with tap water and were anesthetized and blood was placed in non-heparinized tubes (the blood was collected in vials having EDTA as an anticoagulant and left to clot at $4^{\circ} \mathrm{C}$ for $15 \mathrm{~min}$. The sera were separated into aliquots for analysis of blood chemistry. Serum was analyzed for Glucose (mg\%), alanine aminotransferase (ALT) (U/ml) and aspartate aminotransferase (AST) (U/ml) activity.

\section{Pond and water quality parameters management}

Physico-chemical parameters of water in the vicinity of the cages including water temperature, conductivity dissolved oxygen, and $\mathrm{pH}$ were analyzed and recorded on the dike of the pond. For each parameter three samples were tested. Water temperature was measured and monitored daily around 09:00 hours and 13:00 hours GMT using a glass Celsius thermometer. DO was measured using model 57 oxygen meter (YSI industries, Yellow Springs, Ohio, 4387, USA), while a glass electrode $\mathrm{pH}$ meter, Hi-9024 microcomputer (Hanna Instruments Ltd., Chicago, IL., USA), was used to measure $\mathrm{pH}$ values, while electrical conductivity and salinity were determined through conductivity meter (Condi 330i WTW 82362Weilheim Germany). 


\section{Economic analysis}

Economic analysis was conducted to determine economic returns. The analysis was based on market prices in Egypt for harvested fishes and all other items, which were expressed in Egypt .The following simple equation was used according to Asaduzzaman et al., (2006).

$R=I-(F C+V C+I i)$

Where, $R=$ net return, $I=$ income from mono sex tilapia sale, $F C=$ fixed/common costs, $V C=$ variable costs and $I i=$ interest on inputs

The Benefit-cost ratio, BCR was calculated as:

$\mathrm{BCR}=$ net benefit (Total net return) / total expenditure (Total input cost)

Profit index, PI : PI =

$$
\text { (Value of fish } / \mathrm{kg} \text { ) / (Total cost of production). }
$$

$$
\text { Production }\left(\mathrm{Kg} / \mathrm{m}^{2}\right)
$$

Production $\left(\mathrm{Kg} / \mathrm{m}^{2}\right)=($ Total weight of fish harvest $(\mathrm{Kg})) /($ volume of cage $)$.

\section{Statistical analysis}

All the data collected during experiment were recorded and preserved in computer spread sheet. One way analysis of variance (ANOVA) was applied for comparison of the mean values using SPSS (Statistical Package for Social Sciences 2006 version 15.0); and level of significance was based on $p<0.05$ was established .Duncan's Multiple Range Test (DMRT) (Duncan, 1955) was applied to compare means for detection of the level of variation among treatments.

\section{RESULTS AND DISCUSSION}

\section{Water quality parameters}

Water quality parameters of pond and cages were examined to observe any appreciable changes that might have occurred between pond and cages. The overall mean values of each water quality parameter as recorded from different sampling are presented in Table 4. One way analysis of variance (ANOVA) was performed on the data to observe whether any difference exists in different sampling or not. Water quality did not vary significantly $(\mathrm{P}>0.05)$ among treatments, both in cages and in pond over the culture periods.

Table 4: Mean value with standard Error $( \pm$ SE) of water quality parameters as recorded from inside of cages and outside of cages (pond) during the experimental period.

\begin{tabular}{|c|c|c|}
\hline Water quality parameters & Cages & Pond \\
\hline Temperature $\left({ }^{\circ} \mathrm{C}\right)$ & $29.50 \pm 0.10 \mathrm{a}$ & $27.10 \pm 0.3 \mathrm{a}$ \\
\hline Dissolved Oxygen $(\mathrm{mg} / \mathrm{l})$ & $7.11 \pm 0.14 \mathrm{a}$ & $7.70 \pm 0.0 \mathrm{a}$ \\
\hline $\mathrm{pH}(\mathrm{pH}$ unit $)$ & $7.8 \pm 0.54 \mathrm{a}$ & $7.4 \pm 0.0 \mathrm{a}$ \\
\hline Ammonia $\left(\mathrm{NH}_{4}-\mathrm{N}\right)(\mathrm{mg} / \mathrm{l})$ & $0.173 \pm 0.005 \mathrm{a}$ & $0.141 \pm 0.03 \mathrm{a}$ \\
\hline Nitrite $\left(\mathrm{NO}_{2}-\mathrm{N}\right)(\mathrm{mg} / \mathrm{l})$ & $0.09 \pm 0.0002 \mathrm{a}$ & $0.07 \pm 0.03 \mathrm{a}$ \\
\hline Nitrate $\left(\mathrm{NO}_{3}-\mathrm{N}\right)(\mathrm{mg} / \mathrm{l})$ & $0.36 \pm 0.006 \mathrm{~b}$ & $0.21 \pm 0.01 \mathrm{~b}$ \\
\hline
\end{tabular}

$\mathrm{a}=$ no significant level, $\mathrm{b}=$ significant level

The physico-chemical parameters for different samples did not vary, indicating that the water quality parameters had equally affected inside and out side the cages. Water quality in broader sense includes all physical, chemical and biological characteristics of the water. The existence, growth, production and wellbeing of aquatic life are mediated through a chain of interacting physical and 
chemical parameters of water. Moreover, water quality is directly related to the productivity of water body, the growth, production and survival of fish and other aquatic animals. In the present study all values obtained were within the optimal ranges conducive for aquaculture growth and negatively affect the culture of fish. Moreover, the water quality parameters in different cages were same as in the pond water, suggesting that cage culture does not alter the pond environment. Akter (2007) and BFRI (1994) found more or less similar ranges of water quality parameters in their studies indicating that cage culture does not affect the pond productivity.

Influence of partial and complete replacement of soybean meal protein by guar korma (GKM) protein on growth performance of Nile Tilapia fingerlings

The present study used mono sex Nile tilapia (O. niloticus) fingerlings population to reduce variability. Male tilapia grow faster than females (Beardmore et al., 2001) but a study conducted by (Fauconneau et al., 1997) showed that mixed sexes group (males and females) of Nile tilapia had a higher feed intake and lower growth compared to an all male or all female population. However, the all male population had a higher protein efficiency ratio and lower feed conversion ratio compared with the all female population ratio (Fauconneau et al., 1997). Even though most small scale production systems do not sort their fish, it was beneficial to this experiment in order to reduce variability (Beardmore et al., 2001).

The results revealed that averages of initial weights and lengths of the Nile tilapia at the start of the experiment had ranged between $10.0 \pm 0.00$ and $10.04 \pm 0.03$ for weight and $8.5 \pm 0.03$ and $8.6 \pm 0.03$ for length, with insignificant differences among them indicating complete randomization of individual fish among the experimental trials.

Results present in Table (5) show that at the end of the experimental period (16 weeks), maximum final weight were achieved in the experimental fish fed on diet (D2) which contain 9.5\% GKM and diet (D3) contain 18.5\% GKM with averages of 165.66 and $151.72 \mathrm{~g} /$ fish , respectively. However, the lower final weight were noted in experimental fish fed diet (D5) $100 \%$ of GKM with an average of $117.84 \mathrm{~g} /$ fish and diet D4 (27.75\% GKM) with an average of $127.55 \mathrm{~g} / \mathrm{fish}$.

Table 5: Effect of partial and complete replacement of soybean meal by guar korma meal (GKM) on growth performance of mono sex Nile Tilapia (O. niloticus) fingerlings reared in cages in earthen pond system(112 days, three replicates, mean $\pm \mathrm{SE})$

\begin{tabular}{|c|c|c|c|c|c|}
\hline \multirow{2}{*}{ Items } & \multicolumn{3}{|c|}{ Experimental diets (Inclusion level \%) } \\
\cline { 2 - 6 } & $\begin{array}{c}\text { D1(Control) } \\
\text { GKM } \\
0 \%\end{array}$ & $\begin{array}{c}\text { D2 } \\
\text { GKM } \\
9.5 \%\end{array}$ & $\begin{array}{c}\text { D3 } \\
\text { GKM } \\
18.5 \%\end{array}$ & $\begin{array}{c}\text { D4 } \\
\text { GKM } \\
27.75 \%\end{array}$ & $\begin{array}{c}\text { D5 } \\
\text { GKM } \\
37 \%\end{array}$ \\
\hline Initial weight (g/fish) & $10.03 \pm 0.03$ & $10.04 \pm 0.03$ & $10 \pm 0.00$ & $10 \pm 0.00$ & $10.01 \pm 0.00$ \\
\hline Final weight (g/fish) & $\begin{array}{c}138.65 \\
\pm 0.3 \mathrm{c}\end{array}$ & $165.66 \pm 0.9 \mathrm{a}$ & $151.72 \pm 1 \mathrm{~b}$ & $127.55 \pm 1 \mathrm{~d}$ & $117.84 \pm 0.5 \mathrm{e}$ \\
\hline Initial length (cm/fish) & $8.63 \pm 0.03$ & $8.6 \pm 0.03$ & $8.6 \pm 0.06$ & $8.56 \pm 0.03$ & $8.5 \pm 0.06$ \\
\hline Final length (cm/fish) & $18.2 \pm 0.06 \mathrm{a}$ & $18.33 \pm 0.07 \mathrm{a}$ & $18.26 \pm 0.09 \mathrm{a}$ & $17.63 \pm 0.12 \mathrm{~b}$ & $17.36 \pm 0.09 \mathrm{~b}$ \\
\hline Weight gain (g/ fish) & $128.61 \pm 0.3 \mathrm{c}$ & $155.62 \pm 0.8 \mathrm{a}$ & $141.72 \pm 1 \mathrm{~b}$ & $117.56 \pm 1 \mathrm{~d}$ & $107.83 \pm 0.5 \mathrm{e}$ \\
\hline Daily Weight gain (g/fish/day) & $1.14 \pm 0.00 \mathrm{c}$ & $1.39 \pm 0.00 \mathrm{a}$ & $1.26 \pm 0.00 \mathrm{~b}$ & $1.04 \pm 0.00 \mathrm{~d}$ & $0.96 \pm 0.00 \mathrm{e}$ \\
\hline Specific growth rate (\%/day) & $1.05 \pm 0.03 \mathrm{a}$ & $1.09 \pm 0.00 \mathrm{a}$ & $1.08 \pm 0.02 \mathrm{a}$ & $0.98 \pm 0.00 \mathrm{~b}$ & $0.95 \pm 0.00 \mathrm{~b}$ \\
\hline Condition factor (K) & $2.3 \pm 0.02 \mathrm{c}$ & $2.69 \pm 0.02 \mathrm{a}$ & $2.49 \pm 0.04 \mathrm{~b}$ & $2.32 \pm 0.02 \mathrm{c}$ & $2.25 \pm 0.03 \mathrm{c}$ \\
\hline
\end{tabular}

Mean in a row with different superscripts are significantly different $(p<0.05)$.

These results of averages of final fish weights indicated that replacing up to $18.5 \%$ of GKM showed positive effects on growth performances of male Nile tilapia 
fingerlings (O. niloticus) and improvement in body weight was more pronounced in the fish fed on the experimental diet containing up to $18.5 \%$ of GKM to replace $50 \%$ of soybean meal protein. As described in Table (5), results showed that the experimental fish fed on D2 (9.5\% GKM) and D3 (18.5\% GKM) had a significantly $(\mathrm{P}<0.05)$ higher total weight gain compared to the control diet $(0 \% \mathrm{GKM})$ than the rest of the experimental diets, whereas the lowest total weight gain (107.83 g) was achieved by experimental fish fed on diet containing $37 \%$ GKM protein .

The worst growth performance was obtained for experimental fish fed on the experimental diet D5 (37\% GKM protein). On the other hand, the experimental fish fed on diets up to $18.5 \%$ GKM protein had a significantly $(\mathrm{P}<0.05)$ higher specific growth rate $(\mathrm{SGR} \%)$ than the rest of experimental diets. However, at the end of the experiment, the lowest value of SGR was found to be $0.95 \% / \mathrm{d}$ in the experimental fish fed on diet containing $37 \%$ GKM protein. It is interesting to note that, highest value of SGR was observed for the diet 9.5\% GKM protein. The statistical evaluation of data revealed that fish fed on D5 (37\% GKM protein) showed significantly $(\mathrm{P}<0.05)$ lower $\mathrm{K}$ values compared to the other experimental diets, and among them differences in $\mathrm{K}$ values were insignificant (Table 5).Statistical analysis for (SGR\%) indicated that the worst was observed by in fish fed on diet D5 (37\% GKM protein), and insignificantly $(\mathrm{P}<0.05)$ differences compared with control diet (D1).

Significant $(p<0.05)$ increase in average weight gain $(155.62$ and $141.72 \mathrm{~g} / \mathrm{fish})$, daily weight gain (1.39 and $1.26 \mathrm{~g} / \mathrm{fish} /$ day), specific growth rate (1.09 and 1.08 $\%$ /day) and Condition factor (K) (2.69 and 2.49) were observed in fingerlings that fed on diet with $9.5 \%$ and $18.5 \%$ guar meal compared to that of D1 (control diet, $0 \%$ guar meal). However, there was a significant $(p>0.05)$ difference in all the growth indices at 9.5 and $18.5 \%$ guar meal diets compared to control one. When the inclusion of guar meal was increased by more than $18.5 \%$, the fingerlings in all the experimental groups showed significant $(p<0.05)$ decrease in all the growth indices (Table 5).

The negative effect of high levels of guar meal inclusion in experimental diets on growth performance is documented by several researchers and they attributed this effect to guar gum residues in guar meal. These results are in agreement with those of Thakur and Pradhan (1975a), who recorded that the birds consuming lower level of guar korma meal gained more weight than those consumed higher levels of guar meal. Also, Patel and Mc Ginnis (1985) reported that increasing guar meal level in diet decreased BWG.

Influence of partial and complete replacement of soybean meal protein by guar korma (GKM) protein on feed utilization efficiencies:

Averages values of feed utilization in terms of feed intake (FI), feed conversion ratio (FCR), feed efficiency (FE), protein efficiency ratio (PER), productive protein value (PPV) and energy retention (ER) are presented in Table (6). These results indicated that differences in D1 (control) among the experimental diets were insignificant. $(\mathrm{P}<0.05)$. On the other hand, the fish fed on D2 $(9.5 \% \mathrm{GKM})$ or $\mathrm{D} 3(18.5 \% \mathrm{GKM})$ had a significantly $(\mathrm{P}<0.05)$ higher feed intake $(317.4$ and 309.8 $\mathrm{g} /$ fish) than the rest of experimental diets. Whereas the lowest feed intake $(263.5$ $\mathrm{g}$ /fish) was achieved by fish fed on diet containing 37\% GKM (soybean meal protein was $100 \%$ replaced by GKM sources). Results of feed utilization in terms of feed conversion ratio (FCR) are presented in table (6). FCR improved significantly $(\mathrm{P}<0.05)$ using the diets contained treated GKM up to $18.5 \%$.Also, the results of feed efficiency (FE) followed the same trend as (FCR) (Table 6). 
Table 6: Effect of partial and complete replacement of soybean meal (SBM) by guar korma (GKM) on feed utilization efficiencies of mono sex Nile Tilapia (O. niloticus) fingerlings (112 days, mean $\pm \mathrm{SE})$.

\begin{tabular}{|c|c|c|c|c|c|}
\hline \multirow{2}{*}{ Items } & \multicolumn{4}{|c|}{ Experimental diets (Inclusion level \%) } \\
\cline { 2 - 6 } & $\begin{array}{c}\text { D1(Control) } \\
\text { GKM } \\
0 \%\end{array}$ & $\begin{array}{c}\text { D2 } \\
\text { GKM }\end{array}$ & $\begin{array}{c}\text { D3 } \\
\text { GKM }\end{array}$ & $\begin{array}{c}\text { D4 } \\
\text { GKM }\end{array}$ & $\begin{array}{c}\text { GK } \\
\text { GKM } \\
37 \%\end{array}$ \\
\hline Feed intake(FI) (g/fish) & $291.8 \pm 0.9 \mathrm{~b}$ & $317.4 \pm 0.8 \mathrm{a}$ & $309.8 \pm 0.9 \mathrm{a}$ & $274.27 \pm 1.1 \mathrm{c}$ & $262.5 \pm 1.8 \mathrm{~d}$ \\
\hline Feed conversion ratio(FCR) & $2.26 \pm 0.00 \mathrm{~b}$ & $2.04 \pm 0.01 \mathrm{a}$ & $2.18 \pm 0.01 \mathrm{a}$ & $2.33 \pm 0.01 \mathrm{c}$ & $2.43 \pm 0.00 \mathrm{~d}$ \\
\hline Feed efficiency(FE) & $0.44 \pm 0.00 \mathrm{~b}$ & $0.49 \pm 0.00 \mathrm{a}$ & $0.45 \pm 0.00 \mathrm{a}$ & $0.42 \pm 0.00 \mathrm{c}$ & $0.41 \pm 0.00 \mathrm{c}$ \\
\hline Protein intake (g/fish) (PI) & $87.55 \pm 0.26 \mathrm{~b}$ & $95.22 \pm 0.24 \mathrm{a}$ & $92.93 \pm 0.27 \mathrm{a}$ & $82.28 \pm 0.34 \mathrm{c}$ & $78.75 \pm 0.54 \mathrm{~d}$ \\
\hline Protein efficiency Ratio (PER) & $1.46 \pm 0.00 \mathrm{~b}$ & $1.63 \pm 0.01 \mathrm{a}$ & $1.52 \pm 0.01 \mathrm{a}$ & $1.42 \pm 0.01 \mathrm{c}$ & $1.36 \pm 0.00 \mathrm{~d}$ \\
\hline Protein productive value (PPV\%) & $24.88 \pm 0.2 \mathrm{~b}$ & $28.23 \pm 0.2 \mathrm{a}$ & $25.52 \pm 0.3 \mathrm{~b}$ & $23.41 \pm 0.6 \mathrm{c}$ & $21.86 \pm 0.11 \mathrm{~d}$ \\
\hline Protein retention (PR) & $21.78 \pm 0.18 \mathrm{~b}$ & $26.88 \pm 0.17 \mathrm{a}$ & $23.72 \pm 0.22 \mathrm{a}$ & $19.26 \pm 0.45 \mathrm{c}$ & $17.22 \pm 0.03 \mathrm{~d}$ \\
\hline energy retention (ER) & $4.77 \pm 0.6 \mathrm{c}$ & $5.78 \pm 0.5 \mathrm{a}$ & $5.09 \pm 0.52 \mathrm{~b}$ & $4.01 \pm 0.15 \mathrm{~d}$ & $3.53 \pm 0.03 \mathrm{e}$ \\
\hline
\end{tabular}

Mean in a row with different superscripts are significantly different $(\mathrm{p}<0.05)$.

Results also revealed that, the GKM protein sources could replace up to $50 \%$ soybean meal protein in growing Nile tilapia fingerlings without any adverse effects on growth performance and feed utilization parameters . Results of protein efficiency ratio (PER), productive protein value (PPV), energy retention (ER) and energy utilization (EU) of Nile tilapia juvenile fed on experimental diets containing treated peas waste and tomato pomace are presented in table (6). Results revealed that fish diets increased PER, and PPV values significantly $(\mathrm{P}<0.05)$. Concerning protein efficiency ratio (PER) values, it differences in this trial among the fish fed on the experimental diets were significant $(\mathrm{P}<0.05)$. The lower PER percentages obtained for the higher replacing levels ( 75 to $100 \%$ of SBM by GKM) indicating progressive reduction in nutritional value compared to the lower inclusion levels (25 to $50 \%$ of SBM by GKM) .The PER observed in GKM 9.5 dietary group (1.63) were significantly higher $(p<0.05)$ than other dietary groups (Table 6). No significant difference $(p>0.05)$ were observed between GKM 0\%, GKM 9. 5\% and GKM 18.5 $\%$ dietary groups for PER.

Results of energy retention (ER) indicated that experimental fish fed on experimental diets with low GKM significantly $(\mathrm{P}<0.05)$ increased energy utilization (ER and EU). Feed intake (FI) was significantly decreased with increasing GKM. This result disagree with Thakur and Pradhan (1975a); Mishra el al. (2013) and Mohamed (2014), while, agree with Verma and McNab (1982) and Kamran et al. (2002). The decrease in feed intake may be due to that GKM depressed the digestibility of starch and deprive the fish the available energy .The results (Table 6) indicate that the higher level of GKM (more than $18.5 \%$ ), depress feed conversion (FC). These results is in agreement with Thakur and Pradhan (1975a); Kamran et al. (2002). Mishra el al. (2013) found that GKM had a negative effect on FC. The improvement in FC with enzyme supplementation may be due to that GKM decrease glucose metabolism and retarded insulin secretion rates in swine. (Lee et al., 2005). This relatively high substitution level( up to $18.5 \%$ GKM) has to be related to the specific culture conditions. The caged experiment was conducted in a fertilized earthen pond. Therefore it is possible that the fish in the cage experiment got some extra nutrients from the natural pond food, a specific potential strong point of O.niloticus (Rakocy\&Mcginty, 1989). This source of nutrients may have 
supplemented the deficit of essential dietary amino acids. Furthermore, Bowen (1981) reported that tilapias can thrive well on naturally occurring dissolved amino acids.

However, in the current study the good growth recorded in the cages may be due to amino acid utilization from the natural environment, because tilapias feed continuously in a semi-intensive environment. We therefore postulate that the interaction between the natural pond food and GKM may have resulted in an improved dietary amino acid profiles, thus leading to better utilization and growth performance of fish in the cages. This may be due to the extra source of nutrients from the natural pond food, as the pond was fertilized weekly (Lee et al., 2005).

Dietary inclusion of higher level of plant protein affects the palatability of diets in fish species (Boonyaratpalin et al., 1998). In dairy cows, palatability problems have been reported when more than 5\% guar meal was included in the diet (Rahman and Leighton, 1968). It is pertinent to note that even though there was significant reduction in growth indices at higher inclusion of guar meal containing diets, the fingerlings also showed low FCR and high PER. This reflects that increased inclusion of guar meal in the diets showed marked decrease in feed intake and that reflected in FCR and PER. Presence of high level of soluble non starch polysaccharide fraction in the crude fiber content of guar meal is a major limiting factor which affected the nutrient digestibility, growth performance and survival rate of tiger shrimp (Penaeus monodon) fed diets containing higher inclusion level of guar meal by more than $5 \%$. (Moriarty, 1997). where the natural food may have provided an important nutrient supplement, Enes et.al., 2013).

\section{Chemical composition of the whole body:}

Chemical composition of the whole fish body at the beginning and end of the experiment including dry matter (DM), crude protein $(\mathrm{CP})$, ether extract $(\mathrm{EE})$, ash, and gross energy (GE kcal $/ \mathrm{kg})$ are shown in Table (7).

Table (7): Effect of partial and complete replacement of soybean meal (SBM) by guar korma meal (GKM) on the whole body chemical composition \% of Nile tilapia fingerlings (112 days, mean $\pm \mathrm{SE})$.

\begin{tabular}{|c|c|c|c|c|c|c|}
\hline \multirow{2}{*}{$\begin{array}{c}\text { Proximate } \\
\text { composition (\%) }\end{array}$} & At start & $\begin{array}{c}\text { D1(Control) } \\
\text { GKM } \\
0 \%\end{array}$ & \begin{tabular}{c} 
D2 \\
GKM \\
\cline { 3 - 7 }
\end{tabular} & $\begin{array}{c}\text { DK } \% \\
\text { GKM } \\
18.5 \%\end{array}$ & $\begin{array}{c}\text { D4 } \\
\text { GKM } \\
27.75 \%\end{array}$ & $\begin{array}{c}\text { GKM } \\
37 \%\end{array}$ \\
\hline $\begin{array}{c}\text { Dry matter } \\
\text { (DM) }\end{array}$ & $19.26 \pm 01$ & $23.83 \pm 0.1 \mathrm{a}$ & $23.13 \pm 0.2 \mathrm{ab}$ & $23.7 \pm 0.1 \mathrm{a}$ & $23.33 \pm 0.5 \mathrm{ab}$ & $22.67 \pm 0.03 \mathrm{~b}$ \\
\hline $\begin{array}{c}\text { Crude protein } \\
(\mathrm{CP})\end{array}$ & $75.06 \pm 0.11$ & $70.03 \pm 0.17 \mathrm{~b}$ & $71.93 \pm 0.18 \mathrm{a}$ & $71.43 \pm 0.2 \mathrm{a}$ & $69.27 \pm 0.17 \mathrm{c}$ & $69.53 \pm 0.13 \mathrm{bc}$ \\
\hline Total ash & $12.66 \pm 0.02$ & $15.36 \pm 0.14 \mathrm{~b}$ & $15.42 \pm 0.06 \mathrm{c}$ & $15.5 \pm 0.17 \mathrm{~d}$ & $14.5 \pm 0.15 \mathrm{a}$ & $14.36 \pm 0.08 \mathrm{a}$ \\
\hline $\begin{array}{c}\text { Ether extract } \\
\text { (EE) }\end{array}$ & $12.26 \pm 021$ & $14.6 \pm 0.05 \mathrm{a}$ & $13.2 \pm 0.2 \mathrm{a}$ & $12.57 \pm 0.03 \mathrm{a}$ & $16.23 \pm 0.03 \mathrm{~b}$ & $16.1 \pm 0.05 \mathrm{~b}$ \\
\hline $\begin{array}{c}\text { Gross energy } \\
\text { (GE) Kcal/Kg }\end{array}$ & $5391 \pm 0.2$ & $5400 \pm 0.5 \mathrm{c}$ & $5479 \pm 16 \mathrm{~b}$ & $5520 \pm 0.5 \mathrm{a}$ & $5275 \pm 5 \mathrm{~d}$ & $5277 \pm 2 \mathrm{~d}$ \\
\hline $\begin{array}{c}\text { Digestible } \\
\text { energy(DE) }\end{array}$ & $4043 \pm 0.11$ & $4050 \pm 0.4 \mathrm{c}$ & $4109 \pm 12 \mathrm{~b}$ & $4140 \pm 0.4 \mathrm{a}$ & $3956 \pm 4 \mathrm{~d}$ & $3958 \pm 2 \mathrm{~d}$ \\
\hline
\end{tabular}

Mean in a row with different superscripts are significantly different $(p<0.05)$.

\section{The carcass quality was noted as followed}

The highest carcass protein and lipid as well as lowest carcass moisture and ash contents have been detected in the fishes fed on GKM up to $18.5 \%$. No significant $(\mathrm{P}>0.05)$ changes in carcass composition has been observed when fish were fed on different test diets, at each inclusion levels. The carcass dry matter and ash levels 
have increased with all the diet groups comparing to the values at the start of experiment. The values of carcass protein and lipid with diet D2 and D3 were found to be quite similar to that of GKM; and these values were comparatively higher among experimental diet groups.

Averages of DM contents of Nile tilapia fingerlings whole bodies at the experimental diets start was $19.26 \pm 0.1$ and increased significantly $(\mathrm{P}<0.05)$ in all experimental diets groups at the end of the experiment. Results also revealed that crude protein $(\mathrm{CP})$ in whole fish body at the start experimental was significantly $(\mathrm{P}<0.05)$ higher $(75.06 \pm 0.11)$ than that of all experimental diets at the end indicating a decrease in CP parallel with increase in the whole fish body ether extract (EE).

In general these results indicated that $\mathrm{CP} \%$ content in the whole fish bodies is related to EE contents where the increase in one decreases the values of the other. These results also revealed that guar korma meal (GKM) released more potential in fat than soybean meal (SBM) when incorporated in growing Nile tilapia fingerlings. As for fat in tilapia body, it is significantly $(\mathrm{P}<0.05)$ higher for diets (D4 and D5 ) by the increasing levels of soybean meal (SBM) replacement by guar korma meal (GKM) in experimental diets compared to control (100\% soybean meal (SBM). This in agreement with Wang et al., (2005) who reported increasing whole body fat with elevating levels of carbohydrates Averages of whole fish bodies ash \% results revealed that ash $\%$ in whole tilapia bodies was significantly $(\mathrm{P}<0.05)$ lowest at the initial of the experiment (12.66\%) compared to those of all experimental diets at the end of the experiment. At the end of the experiment, the control diets (D1) showed higher $(\mathrm{P}<0.05)$ ash \% $(15.36 \%)$ followed by diets contained guar korma meal (GKM). The lowest ash \% was found in the diet D5 contained guar korma meal (GKM) due to higher ash percentages in soybean meal (SBM) used in the current study.

In the current study Nile tilapia fingerlings showed no negative effects on whole fish bodies proximate composition of incorporation of guar korma meal (GKM) in Nile tilapia diets when compared to the control. Guar korma meal was successfully including in diets of fingerlings with equivalent results (Wang et al., 2005). It appears from the present study that the presence of natural food improved the protein digestibility in guar gum meal based diets in the cage experiment. The mechanism for the improvement may be linked to the presence of algal based diets. Algae or algal based diets are reported to stimulate secretion of copious amount of gastric acid in O. niloticus and O. mossambicus (Bowen 1981).

\section{Fish health}

According to results presented in Table (8), all fish were in very good overall condition regardless of treatment. No visible lesions or other macroscopic pathologies were reported, and histological assessments were also favorable, with a few exceptions.

Table 8: Effect of partial and complete replacement of soybean meal as a source of protein by guar korma (GK) on physiological parameters of Nile tilapia fingerlings.

\begin{tabular}{|c|c|c|c|c|c|}
\hline \multirow{2}{*}{ Items } & \multicolumn{5}{|c|}{ Experimental diets (Inclusion level \%) } \\
\cline { 2 - 6 } & $\begin{array}{c}\text { D1(Control) } \\
\text { GKM 0\% }\end{array}$ & $\begin{array}{c}\text { D2 } \\
\text { GKM 9.5 \% }\end{array}$ & $\begin{array}{c}\text { D3 } \\
\text { GKM 18.5\% }\end{array}$ & $\begin{array}{c}\text { D4 } \\
\text { GKM 27.75 \% }\end{array}$ & $\begin{array}{c}\text { D5 } \\
\text { GKM 37\% }\end{array}$ \\
\hline ALT $(\mathrm{U} / \mathrm{ml})$ & $86 \pm 4 . \mathrm{b}$ & $57 \pm 10 \mathrm{c}$ & $85.5 \pm 3 \mathrm{~b}$ & $99 \pm 9 \mathrm{~b}$ & $145 \pm 0.5 \mathrm{a}$ \\
\hline AST $(\mathrm{U} / \mathrm{ml})$ & $78.5 \pm 3.7 \mathrm{ab}$ & $54.5 \pm 3 \mathrm{~b}$ & $92.5 \pm 1 \mathrm{ab}$ & $102.5 \pm 4 \mathrm{ab}$ & $141 \pm 9 \mathrm{a}$ \\
\hline Glucose $(\mathrm{mg} \%)$ & $103.5 \pm 1.4 \mathrm{~d}$ & $113 \pm 1.7 \mathrm{c}$ & $109.5 \pm 0.8 \mathrm{~cd}$ & $122 \pm 4 \mathrm{~b}$ & $134 \pm 2.8 \mathrm{a}$ \\
\hline
\end{tabular}

Means in the row with different superscripts are significantly different $(\mathrm{p}<0.05)$. 
All fish grew normally, and no specific signs of disease were observed. No mortality was detected throughout the experiment.

Enes et al., (2013) concluded that, dietary inclusion of guar gum up to $12 \%$ did not impair white sea bream growth performance and feed utilization efficiency. Guar gum did not promote a decrease in plasma glucose and cholesterol levels but seems to decrease gluconeogenesis.

\section{Economical evaluation}

Described in Table (9) feed costs (LE) were the highest for the control (D1) diet and gradually decreased with increasing the replacing levels of plant protein sources. The reduction of feed costs was easily observed for the feed costs per Kg weight gain which decreased with increasing incorporation levels of PW or TP. This is in agreement with Eid and Mohamed (2007), who found that feeding costs in fish production is about $50 \%$ of total production costs. This study reports that replacing guar korma with soybean meal decrease feed cost.

\section{Economical Study}

Results of inputs and outputs of the experimental treatments are presented in Table (9). Prices of experimental diets based on feed ingredients in the local market during the experiment were 2.02, 1.71, 1.84 and 1.97 LE for the control, RC, SFM and SSC diets, respectively, which indicated that incorporation of RC, SFM or SSC in tilapia diets to replace $30 \%$ of soybean protein reduced the feed price. Total feed costs during the whole experimental period were 13.47, 11.68, 12.53 and 12.78 L.E. for the same experimental groups cited above, respectively.

Table 9: Effect of substitution of soybean meal with guar korma on economic efficiency of Nile tilapia production.

\begin{tabular}{|c|c|c|c|c|c|}
\hline Items & $\begin{array}{l}\text { D1 } \\
\text { GKM } \\
(\mathbf{0 \%})\end{array}$ & $\begin{array}{c}\mathrm{D} 2 \\
\mathrm{GKM} \\
\mathbf{( 2 5 \% )}\end{array}$ & $\begin{array}{c}\text { D3 } \\
\text { GKM } 0 \\
(50 \%)\end{array}$ & $\begin{array}{c}\text { D4 } \\
\text { GKM } \\
\mathbf{( 7 5 \% )}\end{array}$ & $\begin{array}{c}\text { D5 } \\
\text { GKM } \\
(\mathbf{1 0 0 \%} \\
\mathbf{)}\end{array}$ \\
\hline Guar korma /Kg/100 Kg & 0 & 9.5 & 18.5 & 27.75 & 37 \\
\hline Cost of guar korma/100 Kg & 0 & 36.10 & 70.30 & 105.45 & 140.60 \\
\hline Soybean meal/Kg/100 Kg & 37 & 27.5 & 18.5 & 9.25 & 0 \\
\hline Cost of soybean/100 LE & 188.70 & 140.25 & 94.35 & 47.17 & 0 \\
\hline \multirow[b]{2}{*}{$\begin{array}{l}\text { Change of feed cost due to } \\
\text { addition of guar korma/100 Kg }\end{array}$} & 188.70 & 104.15 & 24.05 & 58.28 & 140.60 \\
\hline & & $\begin{array}{c}\text { Decreasi } \\
\text { ng } \\
\text { cost }\end{array}$ & $\begin{array}{c}\text { Decreasi } \\
\text { ng } \\
\text { Cost } \\
\end{array}$ & $\begin{array}{l}\text { Decreasin } \\
\text { g cost }\end{array}$ & \\
\hline $\begin{array}{l}\text { Cost saving due to completely } \\
\text { replacement of soy bean with } \\
\text { guar korma } / \mathrm{LE} / 100 \mathrm{Kg} \\
\end{array}$ & $\begin{array}{c}48.10 \mathrm{LE} \\
\text { Decreasing cost }\end{array}$ & & & & \\
\hline Weight of fish/kg/100 fish & 16.56 & 15.17 & 13.86 & 12.75 & 11.78 \\
\hline Return /100 fish/LE & 165.60 & 151.70 & 138.60 & 127.50 & 117.80 \\
\hline Return/fish/LE & 1.65 & 1.01 & $1 . \mathrm{r \mu}$ & $1 . r V o$ & $1.1 \mathrm{~V}$ \\
\hline Feed intake (g/fish) & 317.4 & 309.8 & 291.8 & 274.27 & 262.5 \\
\hline $\begin{array}{l}\text { Difference of return from } \\
\text { the } 1^{\text {st }} \text { group/LE }\end{array}$ & - & 14 & 27 & 37 & 48 \\
\hline $\begin{array}{l}\text { Difference of return /LE/fish Due } \\
\text { to partial removal of soya bean } \\
\text { and substitution with guar korma }\end{array}$ & - & 0.14 & 0.27 & $\cdot r v^{2}$ & 0.48 \\
\hline
\end{tabular}


Calculated on basis of Price of guar korma $=3800$ LE. Calculated on the basis of price of soybean $=5100 \mathrm{LE}$.

\section{Calculated according to the price of $\mathrm{Kg} /$ fish $=10 \mathrm{LE}$.}

Economic efficiency (calculated as percentage of revenue to total costs) for C, RC, SFM and SSC treatments were 132.51, 145.70, 145.44 and 149.15 percent respectively. These results indicated that the highest economical efficiency was reported by the SSC group followed in a decreasing order by RC, SFM and control group, respectively. These results indicated that, dried rumen contents or sunflower meal or sesame seed cake can be incorporated in tilapia diets to replace $30 \%$ of soybean meal for better economical efficiency results as well as better growth performance and nutrient utilization. In this connection, Saleh (2001), reported that incorporation of hatchery by product meal or Brewers's dried grain as alternative protein sources in tilapia diets reduced costs of one ton feed mixture. He reported also that similar trend was obtained when yellow corn was replaced by either date stone meal or potato by-products meal. In conclusion this study indicated that guar meal can be used as a promising ingredient in the diet of Nile Tilapia O. niloticus fingerlings up to $18.5 \%$ by replacing $50 \%$ of soybean meal protein and become an alternative plant protein source in fish diet to lower the production cost of fish and add value to the plant origin.

\section{REFERENCES}

Akter, M.; Chowdhury, S. D.; Akter, Y. and Khatun, M. A. (2007). Effect of duckweed (Lemna minor) meal in the diet of laying hen and their performance. Bangladesh Research Publications Journal. 5:252-261.

Altmann, F. (1992). Determination of amino sugars and amino acids in glycoconjugates using precolumn derivatization with OPhthaladehyde. Analytical Biochemistry, 204: 215-219.

ALVA. (1983). Arbeitsgemeinschaft Landwirtschaftlicher Versuchsanstalten in Österreich: Österreichisches Methodenbuch für die Untersuchung von Futtermitteln, Futterzusatzstoffen und Schadstoffen. Wien.

Amirkolaie, A. K.; Leenhouwers, J. I.; Verreth, J. A. J. and Schrama J. W. (2005). Type of dietary fibre (soluble versus insoluble) influences digestion, faeces characteristics and faecal waste production in Nile tilapia. Aquacult. Res., 36: 1157-1166.

Anderson, J. O. and Warnick, R. E. (1964). Sequence in which essential amino acids become limiting for growth of chicks fed rations containing cottonseed meal. Poult. Sci., 45:84-89.

AOAC (2005). Official Methods of Analysis. Association of Official Analytical Chemists. 17th edn, Gaithersburg, Maryland, USA.

Asaduzzaman, M.; Shah, M.K.; Begum, A. Wahab; M.A. and Yang, Yi. (2006). Integrated cage-cum-pond culture systems with highvalued Climbing Perch (Anabas testudineus) in cages and low-valued carps in open ponds. Bangladesh J. Fish. Res., 10(1): 25-34.

Beardmore RE. (2001). A singularity-induced bifurcation theorem for infinitedimensional implicit dynamical systems, Proceedings of the Royal Society A: Mathematical, Physical and Engineering Sciences, 457: 1295-1305.

BFRI (1994). cited in Hossain M.A; Sultana N. and Islam, M.N. (1999). Development of improved methods for the culture of some important marine 
and hyposaline organisms. Final Report. MFIS, BFRI. Mymensingh 2201. 40pp.

Boomyaratpalin, M.; Suraneiranat, P. and Tunpibal, T. (1998). "Replacement of Fish Meal with Vvarious Type of Soybean Products in Diets for the Asian Seabass, Lates calcarifer". Aquaculture, 161: 67-78.

Bowen, S.H., (1981). Detritivory in neotropical fish communities. Environ. Biol. Fish., 9: 137-144.

Brinker, A. (2009). Improving the mechanical characteristics of fecal waste in rainbow trout: the influence of fish size and treatment with non-starch polysaccharide (guar gum). Aquaculture Nutrition, 15: 229-240.

Brinker, A. and Rosch, R. (2005). Factors determining the size of suspended solids in flow-through fish farms. Aquaculture Engineer, 32: 1-19.

Conner, S. (2002). Characterization of Guar for Use in Poultry Ration. Ph.D. Dissertation. Texas. Agricultural and Mechanical University, College Station, TX

Duncan, D. B. (1955). Multiple Range and Multiple F Test. Biometrics, 11: 1-42.

Eid, A., and Mohamed, K. A. (2007). Effect of Using Probiotic as Growth Promoters in Commercial Diets for Mono sex Nile Tilapia (Oreochromis niloticus) Fingerlings. 8th International Symposium on Tilapia in Egypt.

Enes, P.; Pousão-Ferreira, P.; Salmerón, C.; Capilla, E.; Navarro, I.; Gutiérrez, J. and Oliva-Teles, A.(2013). Effect of guar gum on glucose and lipid metabolism in White sea bream Diplodus sargus. Fish Physiol. Biochem., 39: 159-169.

FAO (2012). The State of World Aquaculture and Fisheries 2012. FAO, Rome, Italy. $230 \mathrm{pp}$.

Fauconneau, B.; Chmaitilly, J.; Andre, S.; Cardinal, M.; Cornet, J.; Vallet, J.L.; Dumont, J.P. and Laroche, M., (1997). Caractéristiques de la chair de truite arc en ciel. II. Composantes physiques et sensorielles. Sci. Alim., 13:188-199.

Gupta, N.; Haque, M. M. and Khan, M. (2012). Growth performance of tilapia fingerling in cage in ponds managed by Adivasi households: An assessment through length-weight relationship. J. Bangladesh Agril. Univ. 10(1): 149-155.

Gutierrez, O.; Zhang, C ; Cartwright, A.L. ; Carey, J.B. and Bailey, C.A. (2007). Use of guar by-products in high-production laying hen diets. Poult. Sci., 86: 11151120.

Hassan, S.M.; Gutierrez, O.; Haq, A.U.; Byrd, J.A.; Bailey, C.A. and Cartwright, A.L. (2007). Saponin-rich extracts from quillaja, yucca, soybean and guar differ in antimicrobial and hemolytic activities. Poult. Sci., 86: 121-121.

Hassan, S.M.; Haq A.U.; Byrd, J.A.; Berhow, M.A.; Cartwright, A.L. and Bailey, C.A. (2010). Haemolytic and antimicrobial activities of saponin-rich extracts from guar meal. Food Chem. 119:600-605

Hossain, M.A.; Focken, U. and Becker, K. (2001). Effect of soaking and soaking followed by autoclaving of Sesbania seeds on growth and feed utilisation in common carp, Cyprinus carpio L. Aquaculture 203:133-148. doi:10.1016/S0044- 8486(01)00616-0

Hussain, M.; Rehman, A.U. and Khalid, M.F. (2012). Feeding value of guar meal and the application of enzymes in improving nutritive value for broilers. World's Poultry Science Journal, 68: 253-268.

Iqbal, K. J.; Ashraf, M.; Qureshi, N.A.; Javid, A.; Abbas, F.; Hafeez-ur-Rehman, M.; Rasool, F.; Khan N. and Abbas, S. (2015). Optimizing Growth Potential of Labeorohita Fingerlings Fed on Different Plant Origin Feeds. Pakistan J. Zool. 47(1): 31-36. 
Jobling, M. (1983). Effect of feeding frequency on food intake and growth of Arctic charr, Salvelinus alpinus (L.). J. Fish Biol., 23: 177-185

Kamran Z.; Aslam Mirza M.; Ahsan-ul-Haq and Mahmood, S. (2002). Effect of decreasing dietary protein levels with optimal amino acids profile on the performance of broilers.Pak. Vet. J. 24:161-164.Kaushal, G.P. and I.S. Bhatia (1982). A study of polyphenols in the seeds and leaves of guar (Cyamopsis tetragonoloba L. Taub). J. Sci. Food Agric., 33:461.

Kraugerud, O.F.; Penn, M.; Storebakken, T; Refstie, S.; Krogdahl, A. and Svihus, B. (2007). Nutrient digestibilities and gut function in Atlantic salmon (Salmo salar) fed diets with cellulose or non-starch polysaccharides from soy. Aquaculture 273: 96-107. doi:10.1016/j.aquaculture.2007.09.013.

Kumar, V. Makkar, H.P.S. and Becker, K. (2011). Nutritional, physiological and haematological responses in rainbow trout (Oncorhynchus mykiss) juveniles fed detoxified Jatropha curcas kernel meal. Aquacult Nutr 17:451-467. doi:10. 1111/j.1365-2095.2010.00825.x

Lee, J.T., Connor-Appleton, S.; Cartwright, A. and Bailey, C.A. (2005). Effects of guar meal by-product with and without $\beta$-mannanase hemicell on broiler performance. Poult. Sci., 84: 1261-1267.

Leenhouwers, J.I.; Ter Veld M.; Verreth, J.A.J. and Schrama, J.W. (2007). Digesta characteristics and performance of African catfish (Clarias gariepinus) fed cereal grains that differ in viscosity. Aquaculture 264:330-341. doi:10.1016/j.aquaculture. 2007.01.003

Leenhouwers, J.I.; Adjei-Boateng, D.; Verreth, J.A.J. and Schrama, J.W. (2006). Digesta viscosity, nutrient digestibility and organ weights in African catfish (Clarias gariepinus) fed diets supplemented with different levels of a soluble non-starch polysaccharide. Aquacult Nutr 12:111-116.

Mathur, O. P. and Mathur, C. S. (1989). Feeding of protected protein and urea supplementation for enhanced growth and feed utilization in Magra lambs. Indian J. Anim. Nutr., 6(3): 274-278

Mishra, A., Sarkar, S.K.; Ray, S. and Haldar, S. (2013).Effects of partial replacement of soybean meal with roasted guar korma and supplementation of mannanase on performance and carcass traits of commercial broiler chickens. Vet. World, 6: 693-697.

Mohamed, M.E. (2014). Effect of guar meal inclusion in diet on performance, bacterial population and intestinal of broiler chicks. Egyption J. Nutr. and feeds, 17(2):329-337.

Moriarty, D.(1997). The role of microorganisms in aquaculture ponds. Aquaculture $151,333-349$.

Nagpal, M.L.; Agrawal, O.P. and Bhatia, I.S. (1971). Chemical and biological examination of guar -meal (Cyampsis tetragonoloba L.). Ind. J. Anim. Sci. 4:283-293.

NRC (2010): National Research councile.

Patel, M. B., and J. McGinnis. 1985. The effect of autoclaving and enzyme supplementation of guar meal on the performance of chicks and laying hens. Poult. Sci., 64:1148-1156.

Rahman, A.A.K. and Leighton, Y. (1985). Introduction of Exotic Fishes in Bangladesh. Fisheries Research and Training Centre, (booklet). DOF. Chandpur, Bangladesh. 15p.

Rakocy, J.E. And McGinty, A.S. (1989). Pond culture of tilapia. Southern Regional Aquaculture Center (SRAC) publication No. 280, pp. 1-4. 
Ricker, W.E. (1975). Growth rate and models. W. S. Hoar, D. J. Randall and J. R. Brett,

Saleh, H. D. T. (2001). "The use of non- conventional Energy and protein feed sources in Nile tilapia diets." Ph. D. Thesis Animal Production Department, Faculty of Agriculture, Cairo University.

Shiau S.Y.; Kwok, C.C.; Chen, C.J.; Hong, H.T. and Hsieh, H.B. (1989). Effects of dietary fiber on the intestinal absorption of dextrin, blood sugar level and growth of tilapia, Oreochromis niloticus 9 O. aureus. J. Fish. Biol., 34: 929-935.

Singh, A.K. and W.S. Lakra (2012). Culture of Pangasianodon hypothalamus into India: impacts and present scenario. Pakistan J. Biolog. Sci., 15:19-26.

Storebakken, T. (1985). Binders in fish feeds. I. Effect of alginate and guar gum on growth, digestibility, feed intake and passage through the gastrointestinal tract of rainbow trout. Aquaculture 47:11-26. doi:10.1016/0044-8486(85)90004-3

Tesch, F.W. (1971). Age and Growth. In: Methods for Assessment of Fish Production in Fresh Waters, Ricker, W.E. (Ed.). Blackwell Scientific Publications, Oxford, UK., pp.: 98-103.

Thakur, R.S. and Pradhan, K. (1975a). A note on inclusion of guar meal (Gyamopsis tetragonoloba) in broiler rations. Ind. J. Anim. Sci., 45:98- 102.

Verma, S.V.S. and McNab, J. M. (1982). Guar meal in diets for broiler chickens. Br. Poult. Sci., 23: 95-105.

Wang, X.; Parsons, C. M. and Adams, A. C. (2005). Effect of processing systems on protein quality of feather meal and hog hair meal. Poult. Sci., 76: 491- 496.

\section{ARABIC SUMMARY}

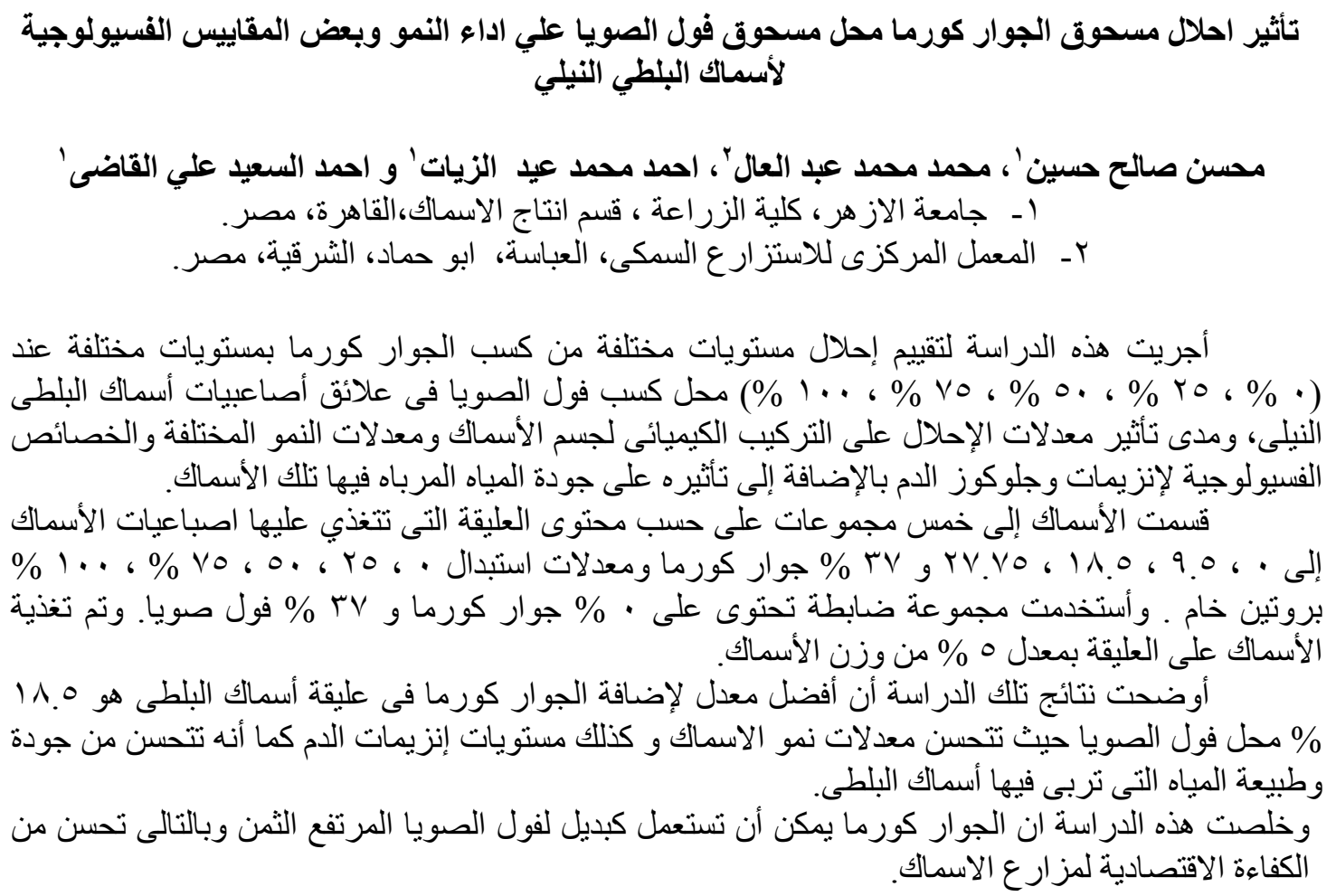

